\section{A polymorphism in exon 2 of the human LDL-receptor gene (LDLR)}

\section{A.K.Soutar}

MRC Lipoprotein Team, Hammersmith Hospital, Ducane

Road, London W12 OHS, UK

Description of Probes: The synthetic oligonucleotides for amplification of exon 2 of the LDL-receptor gene were based on those described by Leitersdorf et al. (1). The allele-specific oligonucleotides for detection of the polymorphism were: $5^{\prime}$ TCT TTC ACA TCT GT (AKS-32) and 5' ACA GAT GCG AAA GA (AKS-31). The polymorphic base is underlined.

Polymorphism: The polymorphism was first identified as a sequence difference between the published sequence for the LDLreceptor DNA (2) and the sequence of the LDL-receptor cDNA obtained from a patient with homozygous familial hypercholesterolaemia (3). The polymorphic site is substitution of $\mathrm{C}$ for $\mathrm{T}$ in the third base of the codon for amino acid residue $\mathrm{Cys}_{6}$ and introduces a recognition site for the restriction enzyme SfaNI. Since the fragments are small it is more convenient to detect the polymorphism by differential oligonucleotide hybridisation.

Protocol: Human genomic DNA was amplified (4) with oligonucleotides flanking exon 2 of the LDL-receptor gene, and the product applied in duplicate to a nylon membrane using standard slot blotting techniques (5). Prehybridisation and hybridisation were carried out each for 1 hour at $29^{\circ} \mathrm{C}$ in $5 \times$ SSPE, $5 \times$ Denhardts and $0.5 \%$ (w/v) SDS (5); for hybridisation the ${ }^{32} \mathrm{P}$ end-labelled oligonucleotide was included at $1 \times 10^{6} \mathrm{cpm} / \mathrm{ml}$. The blots were washed briefly, then twice for $10 \mathrm{~min}$ at $22^{\circ} \mathrm{C}$. Under these conditions the unmatched oligonucleotide does not hybridise with the amplified fragment (see Figure).

Frequency: In 40 normolipaemic individuals from London, UK (non-whites excluded), C-(SfaNI site present) 0.835; T-(SfaNI site absent) 0.165 . The less common variant is that originally described for the human LDL-receptor gene (2).

Mendelian Inheritance: Observed in one family.

References: 1) Leitersdorf,E., Tobin,E.J., Davignon,J. and Hobbs,H.H. (1990) J. Clin. Invest. 85, 1014-1023. 2) Yamamoto,T., Davis,C.G., Brown,M.S., Schneider,W.J., Casey,M.L., Goldstein,J.L. and Russell,D.W. (1984) Cell 39, 27-38. 3) Soutar,A.K., Knight,B.L. and Patel,D.D. (1989) Proc. Natl. Acad. Sci. USA 86, 4166-4170. 4) Saiki,R.K., Bugawan,T.L., Horn,G.T., Mullis,K.B. and Erlich,H.A. (1986) Nature 324, 163-166. 5) Maniatis,T., Fritsch,E.F. and Sambrook,J. (1982) Molecular Cloning: A Laboratory Manual. Cold Spring Harbor Laboratory Press, Cold Spring Harbor, p. 122.

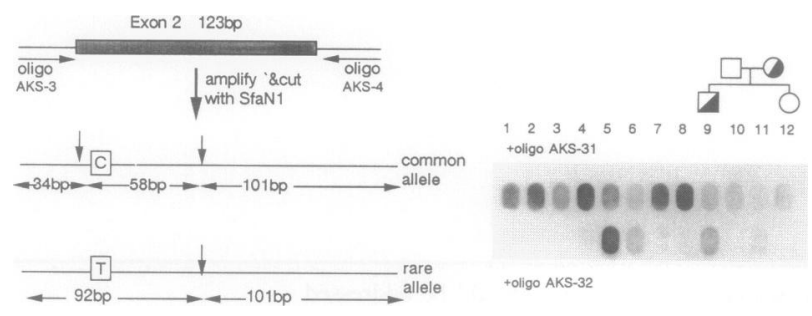

\section{A to $G$ polymorphism in ELN gene}

G.Tromp, A.Christiano', N.Goldstein'2, Z.Indik2, C.Boyd', J.Rosenbloom², S.Deak, D.Prockop and H.Kuivaniemi* Department of Biochemistry and Molecular Biology, and ${ }^{1}$ Department of Dermatology, Jefferson Medical College, Philadelphia, PA 19107, ²Center for Oral Health

Research, University of Pennsylvania, Philadelphia, PA 19104, and ${ }^{3}$ Department of Surgery, UMDNJ-RWJMS, New Brunswick, NJ 08903, USA

Source and Description of Sequence Polymorphism: Sequencing of human elastin cDNA clones revealed a nucleotide variant that converted the codon -AGT- (serine) at amino acid position 422 (1) to -GGT-, (glycine) (2). To determine the frequency of this variant, the PCR was carried out with primers below. Digestion of PCR products with BstNI yielded fragments of $8,11,17,89$, 111,167 and $262 \mathrm{bp}$ for the serine allele, and fragments of 8 , $11,17,18,89,111,167$ and $244 \mathrm{bp}$ for the glycine allele. Digestion of the PCR products with Rmal yielded fragments of 235 and $430 \mathrm{bp}$ for the serine allele and undigested full-length fragment of 665 bp for the glycine allele. BstNI and RmaI digestion of PCR products was used to study 129 unrelated individuals: 37 U.S. Americans, 30 Finns, 14 Swedes, 14 Xhosas, 11 Afrikaners, 7 Canadians, 4 Britons, 3 Italians, 2 Dutch, 2 Greeks, 2 Irish, 2 Japanese and 1 German. Heterozygous individuals were present in all nationalities. All experiments were carried out twice with both restriction endonucleases using two different PCR products from the same individual. Water blanks were negative.

\section{5'-CGCTCTAGACAAGGCCTGGGGGAAATTTACATCC-3' (HELG15 primer in IVS19) \\ 5'-CGCAAGCTTCTGGAGGCCTGGGAGCCAGTTTG-3' (HELG16 primer in IVS21)}

Frequency: Estimated from 258 chromosomes: Serine allele (A) 0.415 and Glycine allele $(\mathrm{G}) 0.585$

$\begin{array}{lrr}\text { A/A } & \text { Expected: } 0.172 & \text { Observed: } \\ \text { A/G } & 0.163 \\ \text { G/G } & 0.343 & 0.504 \\ & & 0.333\end{array}$

Chromosomal Location: 7q11.1-21.1 (3).

Other Comments: Amplification conditions $1 \mathrm{~min} 30 \mathrm{sec}$ at $94^{\circ} \mathrm{C}$, $1 \mathrm{~min}$ at $62^{\circ} \mathrm{C}$ and $1 \mathrm{~min}$ at $72^{\circ} \mathrm{C}$ for 50 cycles.

Acknowledgements: Supported by the Lucille P. Markey Charitable Trust and NIH grants HL 37438 and HL 39869.

References: 1)Indik et al. (1987) Proc. Natl. Acad. Sci. USA 84, 5680-5684. 2) Christiano (1991) Ph.D. Thesis, Rutgers Univ, NJ, USA. 3) Fazio et al. (1991) Am. J. Hum. Genet. 48, 696-703.

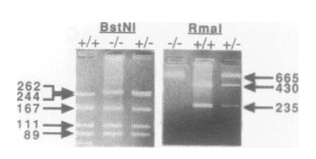

* To whom correspondence should be addressed 